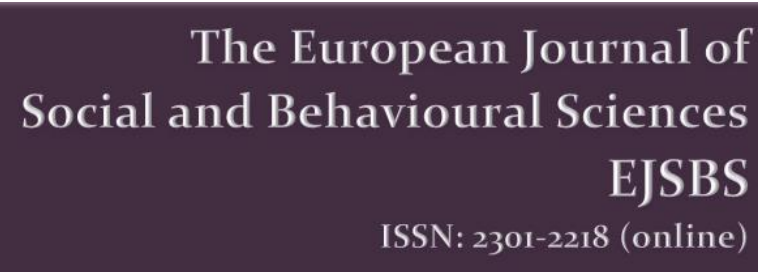

ISSN: 2301-2218 (online)

The European Journal of Social and Behavioural Sciences

EJSBS Volume II (e-ISSN: 2301-2218)

\title{
REASONS OF TURKISH UNIVERSITY STUDENTS PREFERENCE FROM THREE DIFFERENT THERAPEUTIC STYLES
}

\author{
Hakan Usaklia* \\ ${ }^{a}$ Faculty of Education, Sinop University, Sinop 57000, Turkey
}

\begin{abstract}
Three Approaches to Psychotherapy (TAP) Shostrom (1965a, b, c) after watched by 100 Turkish university students evaluated. From one department three deferent programs preschool, elementary and science programs of university students expressed their ideas about Rogers, Perls and Ellis via written statements. $45 \%$ university students preferred Ellis and his therapeutic style. $35 \%$ of students preferred Rogers and his therapeutic style and $20 \%$ university students preferred Perls and his therapeutic style. $85 \%$ university students found Ellis' therapeutic style as realistic. \% 78 university students found Ellis profound and $76 \%$ of university students found Ellis' thematic style as effective. This study is useful for professionals how they develop themselves. Letter studies should conduct on effectiveness of if knowing therapeutic process rise founding help relations for people.
\end{abstract}

Keywords: Therapeutic styles, university students, Turkey

(C) 2012 Published by C-cres. Peer-review under responsibility of Editor(s) or Guest Editor(s) of the EJSBS.

${ }^{*}$ Corresponding author.

E-mail address: husakli@ sinop.edu.tr 


\section{Introduction}

In psychotherapy history Everett Shostrom' Three Approaches to Psychotherapy Shostrom (1965a, b, c) screen out three different oriented psychotherapist's interview with same client. This very useful study psychoeducational material has been using one of the chief educational sources in psychotherapists, psychologists and counselor guidance practitioners' education. This psycho educational film not only use for educational purpose but also fruitful for researches. More than sixty-five years this materials have been using in researchers.

Everett L. Shostrom lived in years between 1921 and 1992. He is known as psychotherapist, author, and film producer. Shostrom was a former president of the American Psychological Association's Div 32 (Humanistic Psychology), and pioneered work producing psychotherapy training films using actual clients. He authored 10 books, and 5 tests and inventories; the most popular in research on psychotherapy outcomes is the Personal Orientation Inventory (Brammer, 1996).

Records study of the videotape series Three Approaches to Psychotherapy (TAP) was recorded in 1964 and released in 1965. Three therapists Carl Rogers, Fritz Perls, and Albert Ellis showed their corresponding approaches of performance with the same volunteer client, Gloria, in the film Three Approaches to Psychotherapy (TAP) (Shostrom, 1965a, b, c). The filming actually took place at around the time of the 1964 annual meeting of the American Psychological Association in Los Angeles. Since 1965, when the 
film was submitted, the counseling profession has consistently and relentlessly embraced TAP as an accurate, timely and realistic description of what RET, and now REBT, is all about despite indications then and now, that the demonstration was seriously flawed and the film is now hopelessly outdated (Weinrach, 2001, p. 44). This is also valid for the other approaches presented in the film. In this collection presents three notable therapists as each practice his approach of therapy to counsel a client identified only as 'Gloria'. TAP features Carl Rogers' illustration of client-centered therapy, Fritz Perls' demonstration of Gestalt therapy, and Albert Ellis' presentation of rationalemotive therapy (Essig \& Russell, 1990; Kiesler \& Goldston, 1988; Konrad \& Yoder, 2000; Shostrom \& Riley, 1968).

A study conducted by Wickman and Campbell (2003) summarize intensive use of the TAP in the researches: Obviously most written about in the history of counseling and continues to be used as an instructional and help model for the helping professions (Glauser \& Bozarth, 2001). TAP is seen as the starting point for the many researches (Bohart, 1991; Dolliver et al., 1980; Ellis, 1986; Essig \& Russell, 1990; Hill, Thames, \& Rardin, 1979; Kiesler \& Goldston, 1988; Meara, Shannon, \& Pepinsky, 1979; Mercier \& Johnson, 1984; Rogers \& Wood, 1974; Rosenzweig, 1996; Shostrom \& Riley, 1968; Stoten \& Goos, 1974; Weinrach, 1986, 1990, 1991; Zimmer \& Cowles, 1972) examining one or more of the counseling sessions or compering two or three of them performing in Three Approaches to Psychotherapy (Shostrom, 1965a, b, c). Recend years' studies are (Bageant 2011; Brice, A. 2011; Keats, 2008; Magai and Haviland-Jones 2004; Reilly \& Jacobus 2008; Reilly \& Jacobus 
2009). This shows continuum of researches on TAP. These researches basically agree that Rogers practiced the theory of counseling for which he is famous. Moreover in contrast of these researchers there are claims on disagreement about this notion (Weinrach, 1990, 1991). Transcribed writings gathered from the films provided by Shostrom (1965a, b, c) or Rogers and Wood (1974) used as qualitative data for analysis.

There are some manipulations in original dialogs for easily reading and understanding. Dialogs spoken in the films seem to be normalized somehow when it transcribed. This makes difficult to utility for counseling of transcripts (Essig \& Russell, 1990; Rogers \& Wood, 1974). Whatever done in the dialogs this Three Approaches to Psychotherapy films have been protecting its importance and vulnerability. To correct the transcript flaws of prior analyses, the first author (Wickman, 1999) improved on existing transcripts by more accurately reflecting the session, including exact words used, lengths of pauses, and changes in volume, tone, or pitch.

In their study "The Hidden Genius of Emotion" Magai and HavilandJones (2004) examined about Three Approaches to Psychotherapy in very wide range.

In Emotion as the Integrative Link in Social and Personality Development part there are Lives Attracted to Shame and Longing: Carl Rogers Lives Repelled by Fear and Distress: Albert Ellis, Lives Repelled and Attracted by Contempt and Shame: Fritz Perls subparts. In Emotion as the Link in Intellectual Work part four subparts that are Wisdom and Passion, Cognitive Stages and Joy, Surprise: Carl Rogers, Cartesian Logic and Anger, Fear: Albert 
Ellis, Dialectical Logic and Excitement, Disgust, and Shame: Fritz Perls available.

The film made as a film series produced by Psychological Films Orange California, developed and created Everett. L. Shostrom (PhD) by filmed and edited by Rod Yould. The film composed of three parts. This psycho educational film is about interweaving with the same client by three different oriented psychotherapists. In the first part of the film is starting with Shostrom's 2 minutes introduction.

Everett. L. Shostrom (1921-1992), psychotherapist, author, and film producer. Shostrom was a former president of the American Psychological Association's Div 32 (Humanistic Psychology), and pioneered work producing psychotherapy training films using actual clients. He authored 10 books, and 5 tests and inventories; the most popular in research on psychotherapy outcomes is the Personal Orientation Inventory (Brammer, 1996). Shostrom is known by Turkish readers by his books, "Kendisi Olamayan Insan Berberi Icin Yalnızca Bir Kelledir" (Shostrom, 1997).

In the film Shostrom (1965a) explains the features of the records. The very first sentence is about what is psychotherapy? As Shostrom (1965a) stated "Psychotherapy is such a personal and private process that it is a mystery to most people who have never gone through it." Then the film as continuous with the Shostrom (1965a) speech: "The following series is a unique effort that allows us to sit in on what is ordinarily a very private therapeutic experience. An actual patient was courageous enough and considerate enough to allow 
herself to be photographed while actually engaged in the therapy with three different therapists."

In the film Shostrom (1965a) explains contend of the material in details. "A film series like this, which three therapists distinguished by their different orientations share their therapeutic endeavors have never been made before. We, therefore, wish to express our gratitude to Gloria the patient and to her therapists for allowing us to share in her therapeutic adventure."

The film summarized as "In 1964 a young divorced mother named "Gloria" volunteers, in an attempt to find some answers to the problems in her life, to be videotaped being a client to three rather new psychotherapies: Person-Centered Therapy, Gestalt Therapy and Rational Emotive Behavior Therapy. Not only is she filmed participating in each therapy, she receiving the therapies from the respective founders of each therapy, Carl Rogers (Part 1, sadly it's cut short), Fritz Perls (Part 2), and Albert Ellis (Part 3). They all take the time before each therapy to explain their methods and their beliefs and how the therapy will go (metafilter.com).

\section{Gloria}

"Three Approaches to Psychotherapy", more popularly known as "The Gloria Films' (amazon.com). In the films Shostrom (1965a, b, c) Gloria, a divorced 30 years old mother of three children, raised questions about how real she should or should not be as a person in relationship with her children. She presented Rogers with her immediate dilemma: How honest should she be with 
her 9-year-old daughter about her sexual relations with men? Her quest for authenticity within herself, as well as in relationship with others, particularly with her children, is captured on celluloid and still viewed in university classrooms around the world (Moon, 2009, p. 287). Gloria' feelings about her daughter that expressed in the films can deeply understand bibliographic book (Burry, 2008). She was consulted about her relations with men, her mother, daughter, father and ex-husband. Both neophyte counselors, as well as seasoned professionals, can still learn a lot from this classic film that has stood the test of time. In my mind it will live forever as an important artifact of the 20th century counseling movement. Today's counselors will watch the movie with one salient difference. They will possess a critical insight we did not have: Simply, that the end of the film was just the beginning for Gloria (Rosenthal, 2005).

Shostrom (1965) explains his feelings in the film as this: "Thus we are allowed the privilege of seeing and feeling what really transpires." Shostrom (1965a) continue to explain the film; "The film composed of three parts ... This series will be dividing the three separate films. In the first film we see Dr. Carl Rogers founder of Client Centered Therapy interviewing Gloria. In film number two Dr. Fredirich Perls founder of Gestalt Therapy is working with her. And in film number three Dr. Albert Ellis founder of Rational Emotive Therapy is our therapist. Each therapist will first describe his system of therapy briefly. He will then demonstrate his work with Gloria and then he will comment briefly on his work. Now here is Dr. Carl Rogers. 
In the original English record of film number one Rogers explain his approach with in about six minutes. He interviewed with Gloria about 31 minutes. And then he evaluates the interview in six minutes.

\section{Carl Rogers}

Carl Ransom Rogers Born in 1902 in Chicago into a strict religious family, Rogers was the fourth of six children. At the University of Wisconsin he studied agriculture, then history, but his aim was to enter the Christian ministry. In 1924 he enrolled at the liberal Union Theological Seminary in New York City, but after two years felt hemmed in by doctrinal beliefs and began taking courses in psychology at Columbia University’s Teachers College. There he obtained his MA in 1928 and his $\mathrm{PhD}$ in 1931. With doctoral work in child psychology, Rogers obtained a post as a psychologist at the Society for the Prevention of Cruelty to Children in Rochester, New York, working with troubled or delinquent children. In 1940, on the strength of his book Clinical Treatment of the Problem Child, he was offered a professorship at Ohio State University. His influential Counseling and Psychotherapy was published in 1942, and in 1945 he began a 12-year posting at the University of Chicago, where he established a counseling center. Client- Centered Therapy (1951) further heightened Rogers' profile, and in 1954 he received the American Psychological Association's first Distinguished Scientific Achievement Award. In 1964 he moved to La Jolla, California, for a position at the Western Behavioral Studies Institute, and remained in California until his death in 1987. He was also well known for his work on encounter groups, 
for his contribution to theories of experiential learning for adults, and for his impact in the area of conflict resolution (Butler-Bowdon, 2007: 241). In his words Rogers (1961) express himself as "I have been a psychotherapist or personal counselor for more than thirty-three years. This means that during a period of a third of a century I have been trying to be of help to a broad sampling of our population: to children, adolescents and adults; to those with educational, vocational, personal and marital problems; to "normal," "neurotic," and "psychotic" individuals (the quotes indicate that for me these are all misleading labels); to individuals who come for help, and those who are sent for help; to those whose problems are minor, and to those whose lives have become utterly desperate and without hope. So, who am I? I am a psychologist whose primary interest, for many years, has been in psychotherapy (Rogers, 1961, p. 7).

The person-centered approach, his own unique approach to understanding personality and human relationships, found wide application in various domains such as psychotherapy and counseling (client-centered therapy), education (student-centered learning), organizations, and other group settings.

In the original English record of film number two Perls explain his approach with in about four minutes. He interviewed with Gloria about 23 minutes. And then he evaluates the interview in three minutes.

Fritz Perls 
Born in 1893 in Berlin, Frederick Salomon Perls gained his medical degree in 1926. On graduating he worked at the Institute for Brain Damaged Soldiers in Frankfurt, where he was influenced by Gestalt psychologists, existential philosophy, and the neo-Freudians Karen Horney and Wilhelm Reich. In the early 1930s, with Germany becoming unsafe for Jews, Perls and his wife Laura moved to the Netherlands and then South Africa. There they established their own psychoanalytic practices and the South African Institute for Psychoanalysis. But they became critical of Freudian concepts, and slowly developed the Gestalt method of practice, articulated in Ego, Hunger and Aggression: A Revision of Freud's Theory and Method (1947). In 1946 the couple moved to New York, setting up an Institute of Gestalt Therapy in 1952. After separating, Fritz moved to California and Laura stayed in New York with their children. He went to Esalen in 1964. The year before he died, Perls published Gestalt Therapy Verbatim (1969), which chronicles sessions held at Esalen, and his autobiography, In and Out of the Garbage Pail (ButlerBowdon, 2007, p. 221).

The gestalt therapy system is truly integrative and includes affective, sensory, cognitive, interpersonal, and behavioral components. In gestalt therapy, therapists and patients are encouraged to be creative in doing the awareness work. There are no prescribed or proscribed techniques in gestalt therapy (Yontef \& Jacobs, 2008, p. 328).

Reilly and Jacobus (2009) used Three Approaches to Psychotherapy the videotape series of second part which cover interview of Perls and Gloria. 97 university students measured by self-devised questionnaire. Students were 
pleased in overall terms with Perls' explanation and presentation of Gestalt therapy. Respondents did not feel Perls treated Gloria respectfully although many students believed that Perls was genuinely interested in her. Students were divided on whether or not to recommend him as a therapist, although a larger percentage disagreed on this point. Results were consistent whether students were defined by section level or class status (Reilly \& Jacobus, 2009, p. 18).

The core of the Gestalt Therapy process is enhanced awareness of sensation, perception, bodily feelings, emotion and behavior, in the present moment. Relationship is emphasized, along with contact between the self, its environment, and the other. Perls has been widely cited outside the realm of psychotherapy for a quotation often described as the "Gestalt prayer". This was especially true in the 1960s, when the version of individualism it expresses was prevalent.

In the original English record of film number three Ellis explained his approach with in about seven minutes. He interviewed with Gloria about 17 minutes. And then he evaluates the interview in five minutes.

\section{Albert Ellis}

Born in 1913 in Pittsburgh, Pennsylvania, Ellis was raised in New York City and died at the age of 94 . He gained a business degree at the City University of New York, and unsuccessfully attempted a career in business. He also tried and failed to become a novelist. Having written some articles on human sexuality, in 1942 Ellis entered the clinical psychology program at 
Columbia University. On obtaining his master's degree in 1943 he launched a part-time private practice in family and sex counseling, and in 1947 earned his doctorate. He held positions at Rutgers and New York University and as a senior clinical psychologist at the Northern New Jersey Mental Hygiene Clinic. Ellis's ideas were slow to be accepted by the American psychological establishment, but today he is considered, along with Aaron Beck, to be the father of cognitive behavior therapy. The Institute for Rational-Emotive Therapy, founded in 1959, continues to disseminate his ideas. See also the biography The Lives of Albert Ellis by Emmet Velten. Ellis was the author of more than 600 academic papers, and his 50- plus books include How to Live with a Neurotic, The Art and Science of Love, Sex Without Guilt, The Art and Science of Rational Eating, and How to Make Yourself Stubbornly Refuse to be Miserable About Anything_-Yes, Anything (Butler-Bowdon, 2007: 77).

The Rational Emotive Behavior Therapy is one of the cognitivebehavioral approaches to psychotherapy. This means that it pays particular attention to the role that cognitions and behavior play in the development and maintenance of people's emotional problems. These specific examples occur in specific 'situations'. Such 'situations' are viewed in the 'situational 'ABC' model as descriptions of actual events about which you form inferences. The situational ' $\mathrm{ABC}$ ' model is rational emotive behavior therapy. In $\mathrm{ABC} A$ stand for activating events B is beliefs and C is for consequences (Dryden \& Branch, 2008 , p. 4). The use of multimedia in the preparation of mental health professionals is likely to increase dramatically in the years to come. The need for accurate, timely and realistic materials is essential to the instructional 
process. The first step in ensuring that students are exposed only to viable videotaped demonstrations is to weed existing collections of outdated materials. Showing students inaccurate materials is worse than not showing them anything at all. Failure to discard outdated materials further fosters the marginalization of REBT. (Weinrach, 2001, p. 52).

In eulogy of Albert Ellis, APA past president Frank Farley states, "Psychology has had only of a handful of legendary figures who not only command attention across much of the discipline but also receive high recognition from the public for their work. Albert Ellis was such a figure, known inside and outside of psychology for his astounding originality, his provocative ideas, and his provocative personality. He bestrode the practice of psychotherapy like a colossus (Farley, 2009).

The aim of this study is to find out what the university students' reasons of preference of therapy style.

\section{Problem Statement}

What are the reasons that effect Turkish university students' preference of psychotherapy style. In this study there are three different psychotherapy approaches are evaluated. Person-Centered Therapy developed by Carl Rogers, Gestalt Therapy developed by Fritz Perls and Rational Emotive Behavior Therapy developed by Albert Ellis. 


\section{Research Questions}

Is there any difference between Turkish university students' preference of psychotherapy style in terms of Person-Centered Therapy developed by Carl Rogers, Gestalt Therapy developed by Fritz Perls and Rational Emotive Behavior Therapy developed by Albert Ellis is the research question of this study.

\section{Purpose of the Study}

The aim of this study is to find out what is the Turkish university students' reasons of preference of here different therapy styles. This study is useful for professionals how they develop themselves. Letter studies should conduct on effectiveness of if knowing therapeutic process rise founding help relations for people.

\section{Research Methods}

Technique of qualitative research is used in this study. Qualitative researches depend on meanings, definitions and experiences of data. Data will consist of mostly words which people define and observe (Coolican, 1992). In the sample of the research 100 Turkish university students joined in the study. Content analysis is one of the most commonly used methods for analyzing qualitative data (Twycross \& Shields, 2008, p.38). 
Comments were made in accordance with the frequencies. In the analysis of the data collected, frequency (f) analysis is to be made and the results obtained are to be presented in table 1.

\section{Findings}

Table 1. Turkish University Students Psychotherapy Preference Reasons

\begin{tabular}{|c|c|c|c|}
\hline Theme & $\mathrm{f}$ & $\%$ & Statement \\
\hline & & & If I have any trouble I would prefer a \\
\hline & & & therapist who is REBT oriented. \\
\hline & & & I prefer Ellis. \\
\hline & & & Ellis is the best of them in all. \\
\hline & & & Ellis has more wisdom. \\
\hline & & & Ellis looks like behaving he is knowing what \\
\hline & & & the client is desire for. \\
\hline & & & If I were Gloria I would prefer Ellis. \\
\hline \multirow[t]{8}{*}{ Preference } & 35 & 35 & I really liked Rogers. I prefer him than \\
\hline & & & others. \\
\hline & & & Rogers is very calm I liked him. \\
\hline & & & Rogers look like a father as Gloria stated this \\
\hline & & & is what I liked in him. \\
\hline & 20 & 20 & Perls look like more sophisticated than \\
\hline & & & others I prefer him. \\
\hline & & & Perls is playing so that's why I prefer. \\
\hline \multirow[t]{2}{*}{ Therapy } & 85 & 85 & I found Albert Ellis' approach more realistic. \\
\hline & & & $\begin{array}{l}\text { The RET or REBT is more useful than other } \\
\text { therapies. }\end{array}$ \\
\hline
\end{tabular}




\begin{tabular}{lll}
\hline Usefulness & 78 & $\begin{array}{l}\text { Except RET other therapies is time } \\
\text { consuming. } \\
\end{array}$ \\
& I believe that Ellis methods works better \\
& them all. \\
& I think Ellis is more effective therapist than \\
& other two therapists. \\
& I think I have also illogical ideas about \\
& myself that I should change them. \\
& I can understand what Ellis means.
\end{tabular}

Preference of three major psychotherapy approaches investigated. Three Approaches to Psychotherapy (TAP) Shostrom (1965a, b, c) after watched by 100 Turkish university students evaluated. From one department three deferent programs preschool, elementary and science programs of university students expressed their ideas about Rogers, Perls and Ellis via written statements. 45 $\%$ university students preferred Ellis and his therapeutic style. $35 \%$ of students preferred Rogers and his therapeutic style and $20 \%$ university students preferred Perls and his therapeutic style. $85 \%$ university students found Ellis' therapeutic style as realistic. \% 78 university students found Ellis profound and $\% 76$ of university students found Ellis' thematic style as effective.

Moreover of these foundlings in the video Shosotrm (1965c) Gloria preferred Perls and Gestalt Therapy approach. This situation criticized by Ellis. Ellis says that Gloria hated Perls for the rest of her life and she said that the interview she had with Everett Shostrom about me and Rogers and Perls was fake. Because at that time, Everett was a devotee of Perls. Perls was very 
ineffective with Gloria and that he did her no good whatsoever, while she seemed to be helped by myself and by Carl Rogers (Rosenthal, 2005).

\section{Conclusions}

Although students have chooses of "none of them" from therapist and approach all of 100 students chosen one of therapy approach Rogers, Perls and Ellis. This shows Turkish university students eagerly to know about psychotherapy approaches although they aren't medicine, psychiatry, psychology, counseling and guidance student.

As a recommendation latter studies should be why people choose one of specific therapy approach and therapist. If there is any affect watching the TAP to visiting psychology health professional? Does interview techniques presented in TAP useful for the people who watched them? In very broad view is there any ecole difference between faculties and institutional in terms of psychology helper professional education. Today's counselors will watch the movie with one salient difference. This means any counselor can be fan of Rogers, Perls or Ellis so Shostrom (1965a, b, c)' TAP make conselors' counseling relation difference.

Shostrom (1965a, b, c) Three Approaches to Psychotherapy (TAP) is very essential educational material. It can be useful for, not only, psychiatrist, psychologist and counselor guidance practitioner but also teachers, nurses and other professionals. Knowing consoling strategies by client can be useful for the sake of counseling session. This educational material can be also useful for 
assertiveness training for woman. Researchers and scholars should help for become popular and separation of the TAP in Turkey. Letter studies should conduct on effectiveness of if knowing therapeutic process rise founding help relations for people.

\section{Acknowledgements}

The authors declare that there is no conflict of interest.

\section{References}

Bageant, R. (2011). The Hakomi Method: Defining Its Place Within the Humanistic Psychology Tradition Journal of Humanistic Psychology 26. https://doi.org/10.1177/0022167811423313

Bohart, A. C. (1991). The missing 249 words: In search of objectivity. Psychotherapy, 28, 497-506. https://doi.org/10.1037/00333204.28.3.497

Brammer, L.M. (1996)." Everett L. Shostrom (1921-1992) - Obituary". The American psychologist, 51(1), 52-52. https://doi.org/10.1037/0003066X.51.1.52

Brice, A. (2011). "If I go back, they'll kill me ..." Person-centered therapy with lesbian and gay clients. Person-Centered \& Experiential Psychotherapies, 10(4), 248-259. https://doi.org/10.1080/ 14779757.2011.626624

Burry, P. J. (2008). Living with the 'Gloria Films': A Daughter's Memory Rosson- Wye. UK: PCCS Books.

Butler-Bowdon, T. (2007). 50 Psychology Classics. Finland: Bookswell. 
Coolican, H. (1992). Research methods and statistics in psychology. London: Hodder \& Stougtton.

Dolliver, R. H., Williams, E., \& Gold, D. C. (1980). The art of Gestalt therapy or: What are you doing with your feet now? Psychotherapy: Theory, Research, and Practice, 17, 136-142. https://doi.org/10.1037/h0085903

Dryden, W., \& Branch, R. (2008). The Fundamentals of Rational Emotive Behaviour Therapy (Second ed.). London: John Wiley \& Sons Ltd. https://doi.org/10.4324/9780203889084

Ellis, A. E. (1986). Comments on Gloria. Psychotherapy, 23, 647-648. https://doi.org/10.1037/h0085671

Essig, T. S., \& Russell, R. L. (1990). Analyzing subjectivity in therapeutic discourse: Rogers, Perls, Ellis, and Gloria revisited. Psychotherapy, 27, 271-281. https://doi.org/10.1037/0033-3204.27.2.271

Farley, F. (2009). Albert Ellis (1913-2007). American Psychologist, 64(3), 215-216. https://doi.org/10.1037/a0015441

Glauser, A. S., \& Bozarth, J. D. (2001). Person-centered counseling: The culture within. Journal of Counseling and Development, 79, 142-147. https://doi.org/10.1002/j.1556-6676.2001.tb01953.x

Hill, C. E., Thames, T. B., \& Rardin, D. K. (1979). Comparison of Rogers, Perls, and Ellis on the Hill Counselor Verbal Response System. Journal of Counseling Psychology, 26, 198-203. https://doi.org/10.1037/00220167.26.3.198

Karasar, N. (2002). Bilimsel Arastirma Yontemi: Kavramlar, Ilkeler, Teknikler [Scientific methods of research: Concepts, principals, techniques]. Ankara: 3A Araştırma Eğitim Danismanlik Ltd. 
Keats, P. A. (2008). Buying into the profession: looking at the impact on students of expert videotape demonstrations in counsellor education. British Journal of Guidance \& Counselling, 36(3), 219-235. https://doi.org/10.1080/03069880802088945

Kiesler, D. J., \& Goldston, C. S. (1988). Client-therapist complementarity: An analysis of the Gloria films. Journal of Counseling Psychology, 35, $127-$ 133. https://doi.org/10.1037/0022-0167.35.2.127

Konrad, J. L., \& Yoder, J. D. (2000). Adding feminist therapy to videotape demonstrations. Teaching of Psychology, 27(1), 57-58.

Magai, C., \& Haviland-Jones, J. (2004). The Hidden Genius of Emotion Lifespan Transformations of Personality. Cambridge: Cambridge University Press.

Meara, N. M., Shannon, J. W., \& Pepinsky, H. B. (1979). Comparison of the stylistic complexity of the language of counselor and client across three theoretical orientations. Journal of Counseling Psychology, 26, 181-189. https://doi.org/10.1037/0022-0167.26.3.181

Mercier, M. A., \& Johnson, M. (1984). Representational system, predicate use and convergence in counseling: Gloria revisited. Journal of Counseling Psychology, 31, 161-169. https://doi.org/10.1037/0022-0167.31.2.161

Moon, K. A. (2009). Pamela J. Burry's Living with “The Gloria Films”': A daughter's Memory. The Humanistic Psychologist, 37, 287-291. https://doi.org/10.1080/08873260903149513

Reilly, J., \& Jacobus, V. (2008). Students Evaluate Carl Rogers and His Relationship With Gloria: A Brief Report. Journal of Humanistic Psychology, 48(1) 32-41. https://doi.org/10.1177/0022167807311944 
Reilly, J., \& Jacobus, V. (2009). Gestalt Therapy: Student Perceptions of Fritz Perls in Three Approaches to Psychotherapy. Australian Journal of Guidance \& Counselling, 19(1), 14-24.

Rogers, C. R., \& Wood, J. K. (1974). Client-centered theory: Carl R. Rogers. In A. Burton (Ed.), Operational theories of personality (pp. 211-258). New York: Bruner/Mazel.

Rogers, C. R. (1961). On Becoming a Person A Therapist's View of Psychotherapy. Boston: Houghton Mifflin.

Rosenthal, H. (2005). Lessons from the Legend of Gloria - Were we duped by the world's most influential counseling session Counselor. The Magazine for Addiction Professionals, 6, 60-66.

Rosenzweig, D. (1996). The case of Gloria. In B. A. Farber, D. C. Brink, \& P. M. Raskin (Eds.), The psychology of Carl Rogers: Cases and commentary (pp. 57-64). New York: Guilford Press.

Shostrom, E. L. (1997). Kendisi Olamayan Insan Berberi Icin Yalnizca Bir Kelledir (Trans. K. Kocatepe). Istanbul: Kuraldisi Yayinevi.

Shostrom, E. L., \& Riley, C. M. D. (1968). Parametric analysis of psychotherapy. Journal of Consulting and Clinical Psychology, 32, 628632. https://doi.org/10.1037/h0026596

Shostrom, E. L. (Producer). (1965a). Three approaches to psychotherapy [Film and videotape]. (Part 1-Carl Rogers). (Available from Psychological Films, Orange, CA).

Shostrom, E. L. (Producer). (1965b). Three approaches to psychotherapy [Film and videotape]. (Part 2-Fritz Perls). (Available from Psychological Films, Orange, CA). 
Shostrom, E. L. (Producer). (1965c). Three approaches to psychotherapy [Film and videotape]. (Part 3-Albert Ellis). (Available from Psychological Films, Orange, CA).

Stoten, J., \& Goos, W. (1974). Three psychotherapies examined: Ellis, Rogers, Perls. The Alberta Journal of Educational Research, 20, 103-115.

Twycross, A., \& Shields, L. (2008). Content analysis. Paediatric Nursing, 20(6), 38. https://doi.org/10.7748/paed.20.6.38.s27

Weinrach, S. G. (2001). Collaborators in the Marginalization of Rebt-The Use and Misuse of Three Approaches to Psychotherapy and Other Videotaped Demonstrations. Journal of Rational-Emotive \& CognitiveBehavior Therapy 19, 1. https://doi.org/10.1023/A:1007895216709

Weinrach, S. G. (1991). Rogers' encounter with Gloria: What did Rogers know and when? Psychotherapy, 28, 504-506. https://doi.org/10.1037/00333204.28.3.504

Weinrach, S. G. (1990). Rogers and Gloria: The controversial film and the enduring relationship. Psychotherapy, 27, 282-290. https://doi.org/10.1037/0033-3204.27.2.282

Weinrach, S. G. (1986). Ellis and Gloria: Positive or negative model? Psychotherapy, 23, 642-647. https://doi.org/10.1037/h0085670

Wickman, S. A. (1999). "Making something of it": An analysis of the conversation and language of Carl Rogers and Gloria. Unpublished doctoral dissertation, Southern Illinois University, Carbondale.

Wickman, S. A., \& Campbell, C. (2003). An analysis of how Carl Rogers enacted client-centered conversation with Gloria. Journal of Counseling \& Development, 178-184. $\quad$ https://doi.org/10.1002/j.15566678.2003.tb00239.x 
www.amazon.com/Living-gloria-Films-Pamela-Burry/dp/1906254028

February 2012)

www.metafilter.com/69825/The-Gloria-Tapes (03 January 2012)

Yonterf, G. \& Jacobs, L. (2008). Gestalt Therapy. In N. J. Raskin, \& M. C. Witty (Eds,), Current Psychotherapies (8th ed.) (pp. 328-367). California: Thomson Brooks/Cole.

Zimmer, J. M., \& Cowles, K. H. (1972). Content analysis using FORTRAN: Applied to interviews conducted by C. Rogers, F. Perls, and A. Ellis. Journal of Counseling Psychology, 19, 161-166. https://doi.org/10.1037/h0032429 